\title{
A 15 cm-es 1861M gránát története
}

A z Osztrák-Magyar Monarchia tüzérségének fejlődésében nagy szerepet játszott a huzagolt csövű ágyúk megjelenése. Az első ilyen a francia Jean Ernest Ducos de La Hitte tüzér tábornok által 1858-ban szerkesztett ágyú volt. A La Hitte rendszerű ágyúk bronzcsövűek és még elöltöltősek voltak. A lövedékek megvezetésére és megforgatására a lövedékek palástjára sárgaréz korongokat, ún. szemölcsöket szereltek. Ezekből az ágyúkból az 1859-ben kitört szárd-francia-osztrák háborúban az osztrák tüzérek 36 saját gyártású üteggel vettek részt. $A$ La Hitte rendszerű ágyúk és lövedékek tanulmányozásának eredményeként több régebbi ágyú csövét alakították át ilyen huzagolt rendszerre. 1861-ben megkezdődött a Lenk von Wolfsberg báró által fejlesztett ún. lőgyapot-ágyúk rendszeresítése. Ezek az ágyúk nem váltották be a hozzájuk füzött reményeket, ezért a gyártásukat 1863-ban beszüntették. Még abban az évben a tüzérséget ún. ívhuzagolt csövű ágyúkkal látták el. Az 1863M néven rendszerbe állított elöltöltős ágyúk és lövedékek 7, 8 és 10 cm-es (3, 4 és 8 fontos) űrméretűek voltak. Az öntöttvas lövedéktestre öntéssel és sajtolással rögzítették az ágyú huzagolásának megfelelő profilú ónötvözetből készült palástot. Az ágyúkhoz feketelőpor-töltetű gránátokat, srapneleket, valamint gyújtógránátokat és kartácsokat gyártottak. Ezek kilövéséhez zsákba töltött feketelőport és az ágyúcső hátsó részébe helyezett 1859M dörzsgyújtót használtak. Még 1861ben az osztrák-magyar tüzérség a svéd Martin von Wahrendorff báró (1798-1861) által az 1840-50-es években konstruált ágyúk bevezetését is elkezdte. Wahrendorff ágyúi öntöttvasból készültek. A dugattyús závárzatú ágyúk már hátultöltősek voltak. A závárzat felé a lőporgázok szö-

1. ábra. A Wahrendorff-rendszerü ágyúcső a bádogcsészébe helyezett papírkoronggal, és a závárzat

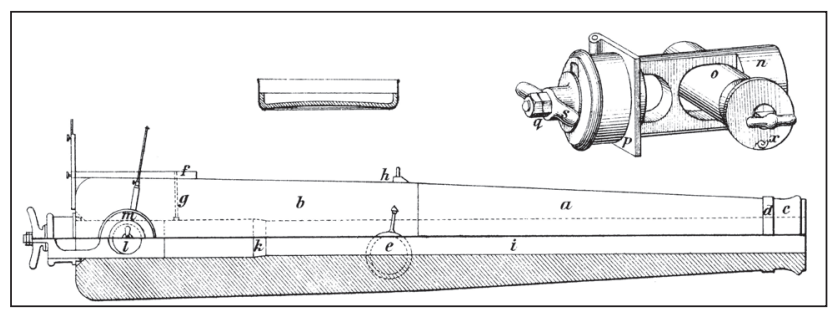

kését egy bádog csésze és az abban elhelyezett papírkorong akadályozta meg. Lövés előtt először a lövedéket, majd a zsákba töltött feketelőport helyezték a töltényűrbe. Ezután hátulról betolták a bádog csészével együtt a závárzatot és a csőfar oldalsó furatain keresztül átdugtak a závárzat első nyílásán egy rudat. Végül a závárzat végén lévő csavart megszorították. A lövés kiváltásához szükséges dörzsgyújtót a csőfar felső felébe kellett behelyezni. Wahrendorff nemcsak az ágyúkat, hanem a hozzájuk tartozó lövedékeket is maga tervezte. Ez utóbbiak jellegzetessége a nagy méretű ólomköpeny.

1861 januárjában megkezdődött az ágyúk gyártása a bécsi tüzérszertárban

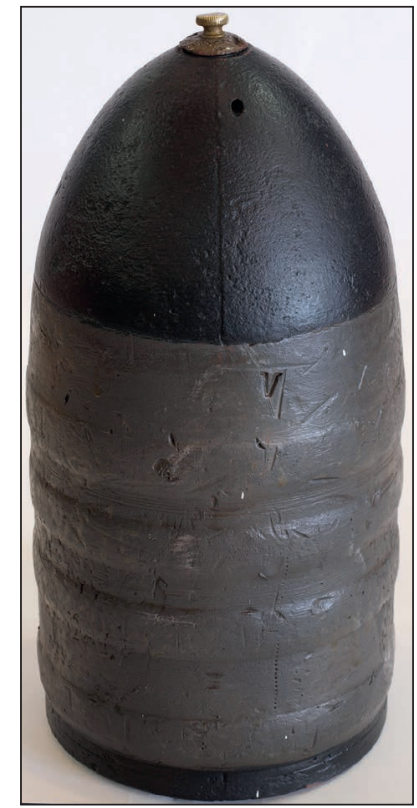

2. ábra. $15 \mathrm{~cm}$-es $1861 \mathrm{M}$ gránát a gyújtószerkezetével (K.u.k Artilleriezeugsfabrik, Arsenal) és a mariazelli ágyúgyárban (Gusswerk bei Maria-Zell). Az itt készült csöveket 1859M ágyútalpakra szerelték. Az első éleslövészetre 1861. február 19-én került sor Ferenc József császár jelenlétében. A Wahrendorff-rendszerű ágyúkat a tábori és a vártüzérség 9, 12 és $15 \mathrm{~cm}$-es űrméretben rendszeresítette többféle lövegtalppal. A $15 \mathrm{~cm}$-esekhez srapnelt, kartácsot, gyújtógránátot és gránátot rendszeresítettek. A $15 \mathrm{~cm}$-es Wahrendorff ágyút a császári és királyi haditengerészet is rendszerbe állította $15 \mathrm{~cm} \mathrm{L/21} \mathrm{(a} \mathrm{csőhossz}$ az űrméret huszonegyszerese) megnevezéssel. Ilyen ágyúk kerültek például a PRINZ EUGEN fedélzetére 1863-ban, a HELGOLANDRA 1870-ben és a LAJTA monitorra 1871ben.

Az 1880-90-es években a tábori és a haditengerészeti tüzérség is leváltotta a Wahrendorff-rendszerű ágyúit és korszerübb 1880M és 1899M ágyúkat rendszeresítettek.

ÖSSZEFOGLALÁS: Az Osztrák-Magyar Monarchia tüzérsége az 1. világháború idején már rendelkezett új tervezésű, modern gránátokkal, de az elhúzódó háború miatt lőszerhiány lépett fel. Ennek egyik megoldása a régi tervezésü gránátok „átgondolása” volt. llyen gránát volt az az 1861-ben rendszeresített gránát is, amelyet felújítva 1918-ig rendszerben tartottak és alkalmaztak.
ABSTRACT: The artillery of the Austro-Hungarian Monarchy had already had modern grenades of a new design during the World War I, but there was a lack of ammunition due to the protracted war. One solution to this was the "rethinking" of previously-designed grenades. Such a grenade was the 1861 the grenade entered into service in 1861, which was retrofitted and applied until 1918.

KULCSSZAVAK: 1. világháború, tüzérség, gyújtószerkezet, gránát, 1861M, ólomköpeny

* MH 1. Honvéd Tűzszerész és Hadihajós Ezred, 1. osztályú tűzszerész, kiképző (Hungarian Defence Forces 1st EOD and River fleet Regiment, EOD team leader and EOD trainer). ORCID: 0000-0002-2220-8852 
A vártüzérség azonban hagyományőrzőnek bizonyult és az 1861M ágyúk módosított változatait (1861/80M és 1861/95M) használta.

$A z$ I. világháborúban hamar kiderült, hogy az egyébként modern osztrák-magyar tüzérség ágyúinak száma nem elég a többfrontos háború megvívásához. Ez azt eredményezte, hogy az elavultnak számító löveganyagot is a frontra vezényelték. Így került több $15 \mathrm{~cm}$-es $1861 \mathrm{M}$ ágyú a tiroli frontra és a karszt fennsíkra is. Természetesen a Przemysliben állomásozó vártüzér alakulatok a háború kitörése előtt is rendelkeztek Wahrendorff ágyúkkal.

A rendszeresített gránátok közül a 15 cm-es, $1861 \mathrm{M}$ gránát története tekinthető érdekesnek. A gránátot 1861ben rendszeresítették a hozzá tartozó $1861 \mathrm{M}$ gránát gyújtószerkezettel. A gránát az eredeti terveknek megfelelően bordákkal ellátott öntöttvasból készült. Az öntés technológiája miatt a gránáttest alján egy menetes furatot találunk, ami a feketelőpor betöltését is elősegítette. Ebbe a furatba került a zárócsavar, amit betekerése előtt valószínűleg szigetelő anyagba mártottak, így kerülve el a kilövés közben a gázok bejutását a lőporhoz. A gránáttestre öntötték az ólomköpenyt, ami a bordákba kapaszkodva kibírta a kilövéskor fellépő erőhatásokat. $A$ köpeny feladata a gránát megforgatása volt a cső huzagolásán keresztül, a gránát központozása a csőben és a lőporgázok tömítése a csőszáj irányába addig, amíg a gránát a csőben haladt. Becsapódáskor a gránátot az orrába szerelt gyújtószerkezet robbantotta fel. Mai kifejezésekkel élve a gyújtószerkezet

\section{3. ábra. Az 1861M gránát gyújtószerkezet rajza}

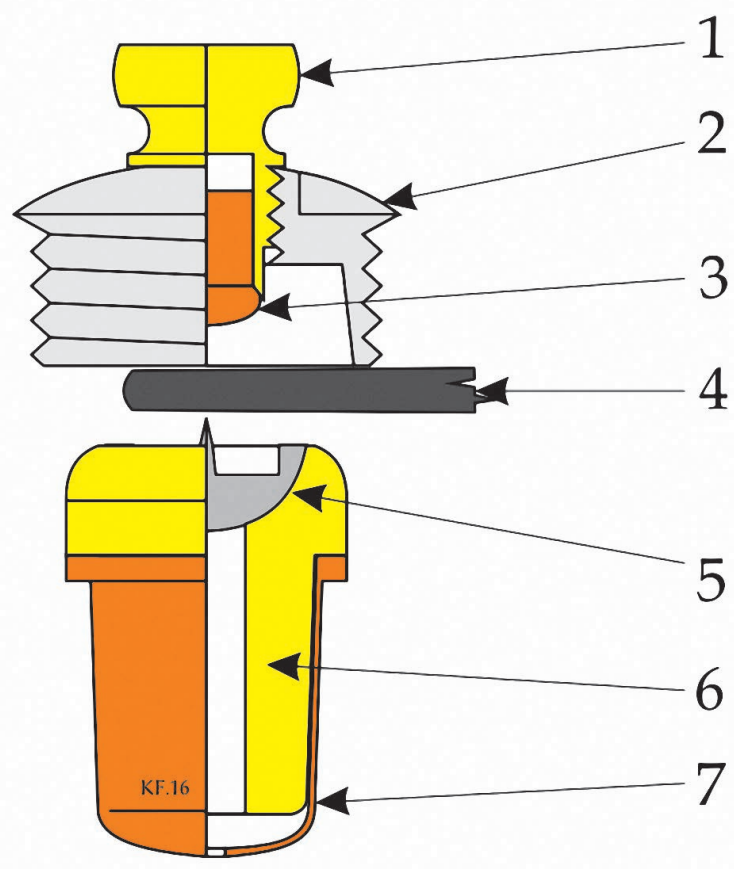

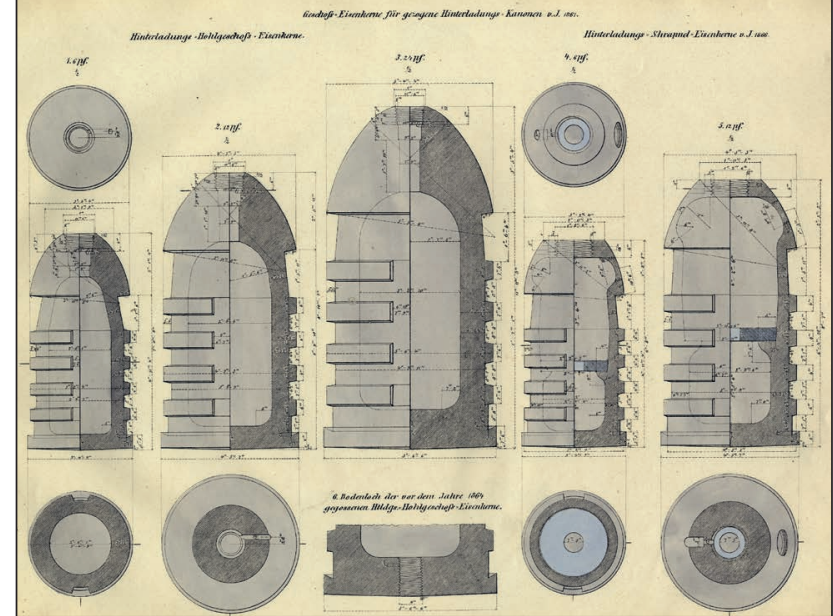

4. ábra. 1861M gránátok és srapnelek rajza. Alul, középen az 1864-ig gyártott fenékcsavaros változat

egy centrifugális kibiztosítású, biztosítás nélküli, tehetetlenségi csapódó gyújtószerkezet (3. ábra).

A gyújtószerkezet felső része (2) tartalmazza a vörösrézből készült ólomazidos csappantyúval (3) szerelt sárgaréz csappantyútartó csavart (1). Az alsó része a gránáttestben helyezkedik el. Ez egy vörösréz perselyből (7) és az ütőtestből (6) áll. Az ütőtest (6) felső felében található az íves, vas ütőszeg (5). A gyújtószerkezet felső és alsó részét a biztosítórúd (4) tartja távol egymástól. A biztosítórudat a gránáttest felső részén lévő furaton keresztül tolták a gyújtószerkezetbe (4). Kilövéskor, amíg a gránát a csőben halad, a gyújtószerkezetben nem áll be változás. Amint a gránát elhagyta a csövet, a biztosítórúd (4) a gránát forgása következtében fellépő centrifugális erő hatására a gránáttestből kirepül. Ekkor megszűnik a gyújtószerkezet alsó és felső része között az elszigetelés és a gyújtószerkezet éles helyzetbe kerül. A gránát becsapódásakor az ütőtest (6) az ütőszeggel (5) együtt előrevágódik és belecsap a csappantyúba (3). A csappantyúban (3) keletkező láng az ütőszeg mellett és a persely (7) furatán keresztül meggyújtja a gránát 0,91 kg-os feketelőpor-töltetét, ami zárt térben felrobban. A robbanás következtében az öntvény gránáttest és a rajta lévő ólomköpeny darabokra szakad. A gránáthoz 2 féle lőporzsákot használtak, 1,12 vagy 2,15 kg feketelőpor töltettel.

1864-től elhagyták a gránát aljáról a csavart. Ennek két fő oka volt. Az egyik az öntési eljárás korszerűsítése, a másik az, hogy a gránáttestbe bejutó lőporgázok csőrobbanást okozhattak. A gránát teljes hossza $312 \mathrm{~mm}$, a tömege $27,83 \mathrm{~kg}$ volt. A kilövéshez szükséges feketelőpor töltetet selyem vagy vászonzsákba töltötték. A zsák száját madzaggal bekötötték és a töltet súlyát ráfestették a zsák oldalára. A Steinben (K.u.k Pulverfabrik in Stein) készült lőport tartalmazó zsákok „St. P.” jelölést is kaptak. A töltet begyújtását az 1859M dörzsgyújtó végezte. Ezt az ágyúcsőbe helyezés után a dörzsgyújtó drótjára kötött zsinórral

1. táblázat.

\begin{tabular}{|c|c|c|c|c|c|c|}
\hline Töltet & Távolság & Becsapódás & Becsapódási & \multicolumn{3}{|c|}{ A keletkezett tölcsér } \\
\cline { 5 - 7 } tömege & & sebessége & szög & mélysége & magassága & szélessége \\
\hline ismeretlen & $1365 \mathrm{~m}$ & $269 \mathrm{~m} / \mathrm{s}$ & $4^{\circ} 55^{\prime}$ & $0,55 \mathrm{~m}$ & $0,90 \mathrm{~m}$ & $0,90 \mathrm{~m}$ \\
\hline $2,15 \mathrm{~kg}$ & $910 \mathrm{~m}$ & $280 \mathrm{~m} / \mathrm{s}$ & $3^{\circ} 30^{\prime}$ & $0,90 \mathrm{~m}$ & $1,26 \mathrm{~m}$ & $1,29 \mathrm{~m}$ \\
\hline $1,12 \mathrm{~kg}$ & $1365 \mathrm{~m}$ & $187 \mathrm{~m} / \mathrm{s}$ & $10^{\circ} 20^{\prime}$ & $0,37 \mathrm{~m}$ & $1,9 \mathrm{~m}$ & $0,5 \mathrm{~m}$ \\
\hline
\end{tabular}




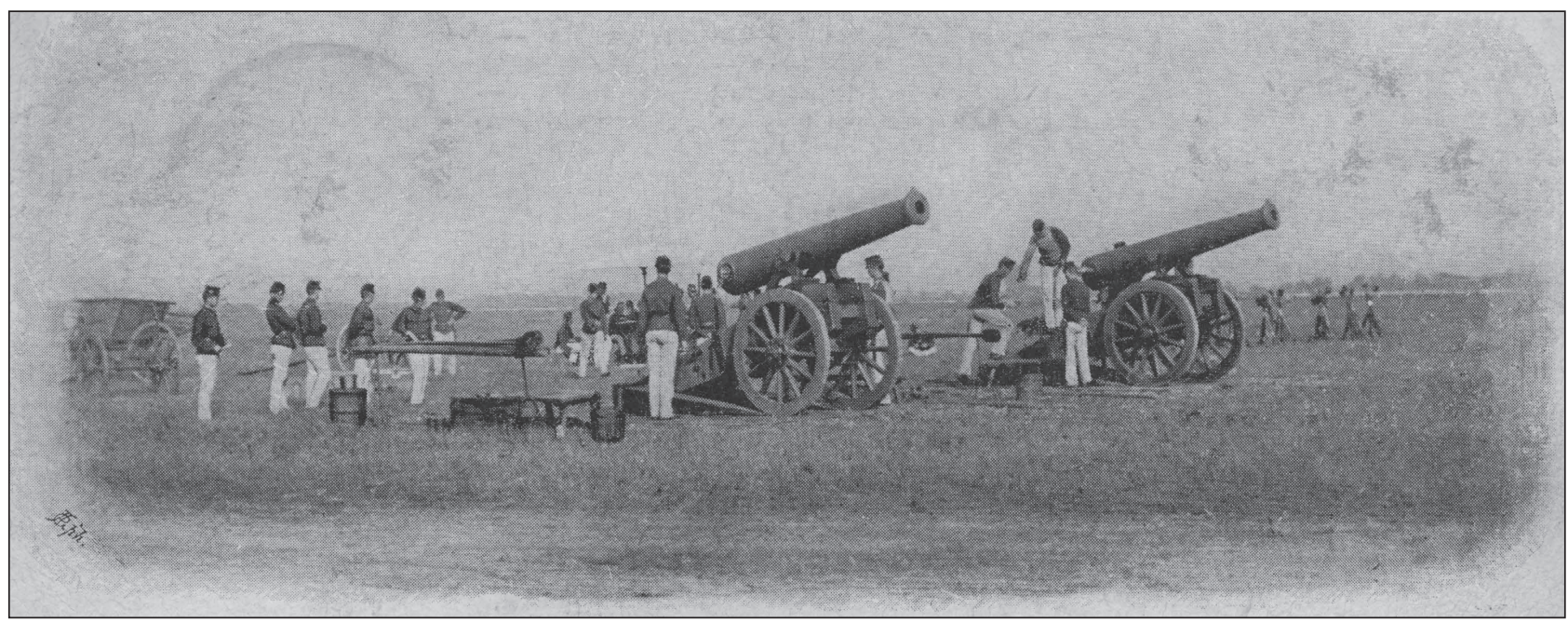

5. ábra. 15 cm-es $1861 M$ ágyúk egy 1907-ben rendezett hadgyakorlaton

hozták működésbe. A dörzsgyújtó lényegében a ma is használt gyufa elvén működik. A drót megrántásakor a végénél lévő dörzsölésre érzékeny anyag meggyullad és begyújtja az alá helyezett lőport, ami a végigégése után a lőporzsák töltetét gyújtotta meg. Még az 1860-as években megtörtént a gránátok hatásainak vizsgálata is. Erre a célra az 1860-ban épült azzanói Wratislaw erőd (werk Neu Wratislaw) egyik falát jelölték ki. A téglából és mészkőből vegyesen épült falra leadott lövések a következő eredményt adták:

$\mathrm{Az}$ ismeretlen töltet tömege valószínűleg 2,15 kg-nál több lehetett. Erre enged következtetni, hogy a gránát becsapódási sebessége 1365 méter megtétele után is $269 \mathrm{~m} / \mathrm{s}$ volt.

1895-ben, amikor az 1861M ágyúkat modernizálták, az ágyúk nemcsak új lövegtalpat, hanem új lőportölteteket is kaptak. Erre azért volt szükség, mert az új, 3 különböző

\section{6. ábra. Az 1861/1M gránát gyújtószerkezetének rajza}

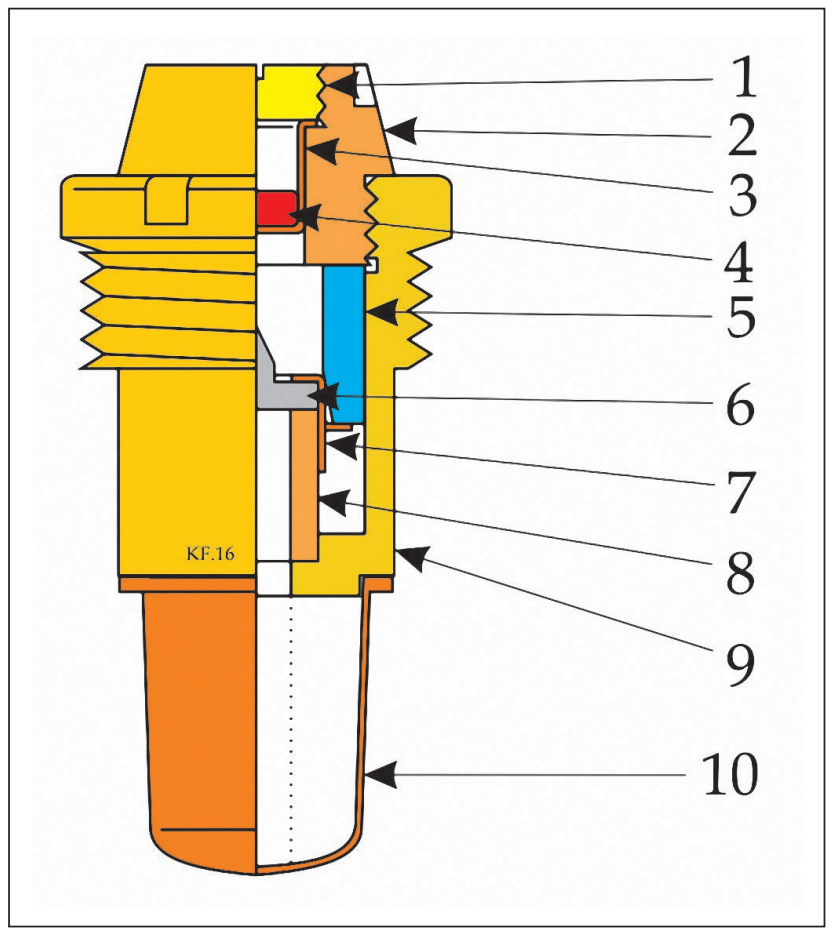

tömegű töltettel többfajta lőfeladatot lehetett végrehajtani és a gránát lőtávolsága így 6400 méterre növekedett. A töltetek két fajta lőporból készültek. Steini „Lit. A.” lőpor esetén $0,85 \mathrm{~kg}, 1,45 \mathrm{~kg}$ és 2,15 kg-os, 7 mm-es löveglőpor esetén $1 \mathrm{~kg}, 1,58 \mathrm{~kg}$ illetve 2,35 kg-os tömegben. A töltet begyújtásához már 1893M dörzsgyújtót alkalmaztak. 2,15 kg-os töltet esetén a gránát, átlagos talajba, 1517 méter távolságon egy $80 \mathrm{~cm}$ mélységű és $190 \mathrm{~cm}$ átmérőjü krátert ütött.

1901-ben a gránáthoz új gyújtószerkezetet terveztek és rendszeresítettek $1901 \mathrm{M}$ gránát gyújtószerkezet néven. Az ezzel a gyújtószerkezettel szerelt gránátok elnevezése 1861/1M gránátra változott. Tervezésénél figyelembe vették azokat a követelményeket, hogy az új gyújtószerkezettel ellátott gránát teljes hossza és tömege nem térhet el az eredeti $1861 \mathrm{M}$ gránátétól. Az eredmény egy tehetetlenségi kibiztosítású, biztosítás nélküli, tehetetlenségi csapódó gyújtószerkezet lett (6. ábra).

A kialakítása az akkor már rendszerben lévő $1875 \mathrm{M}$ és $1880 \mathrm{M}$ gránát gyújtószerkezetekhez hasonló. Felső felében helyezkedik el a csappantyút (4) tartalmazó csésze (3), amit a fejcsavar (2) rögzít. A fejcsavar (2) felülről egy zárócsavarral (1) le van fedve. A gyújtótest (9) aljában áll az ütőtest (8) a beleszerelt ütőszeggel (6). Az ütőtest tetején nyugszik a biztosítólemez (7), ami a 4 kihajló karmával támasztja alá a biztosítóhüvelyt (5). Alaphelyzetben ez a hüvely távol tartja az ütőtestet (8) a fejcsavartól, (2) illetve a csappantyútól (4).

7. ábra. Az 1901M gránát gyújtószerkezetének alkatrészei a biztosító lemez és a csappantyú nélkül

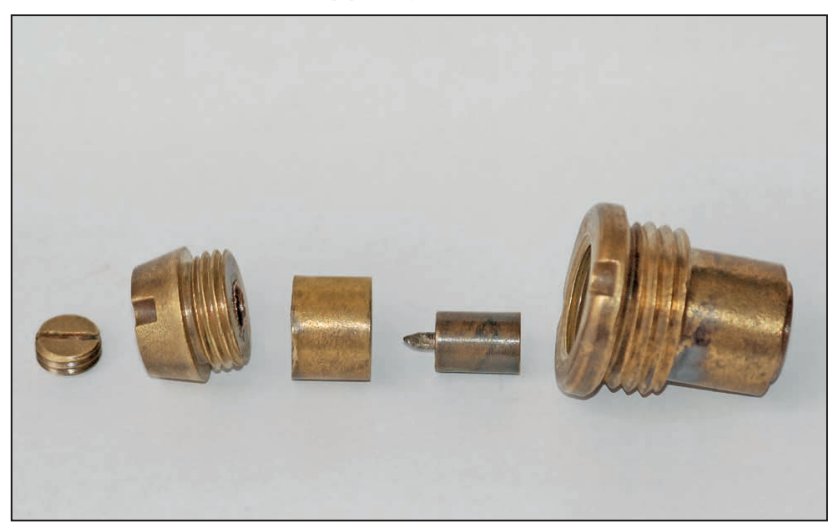


Kilövéskor a fellépő tehetetlenségi erő miatt a biztosítóhüvely (5) lesüllyed, miközben a biztosítólemez (7) karmait lehajlítja. Ennek eredményeként a biztosítóhüvely (5) még a csőben rászorul az ütőtestre (8). A gyújtószerkezet éles állapotba került. Ez a megoldás az $1861 \mathrm{M}$ gyújtószerkezethez képest biztonsági szempontból visszalépés volt, ugyanis az $1861 \mathrm{M}$ gyújtószerkezet csak a cső elhagyása után élesedik ki, ezért a csőrobbanás esélye ennél kisebb.

Becsapódáskor az ütőtest (8) a rászorult biztosítóhüvelylyel (5) együtt előre vágódik, mialatt az ütőszeg (6) a csappantyúba (4) szúr. A keletkező láng az ütőszeg (6) mellett, az ütőtest (8) furatán keresztül gyújtja a gyújtótest (9) alá helyezett erősítő lőportöltetet (10), ami detonátorként funkcionálva robbantja a gránát lőpor töltetét.

Az 1901M gyújtószerkezetek a hirtenbergi Fridolin Keller fémárúgyárában (Fridolin Keller Metallwarenfabrik in Hirtenberg) készültek. Ez a cég 1917-től Első Osztrák Gyújtószerkezet- és Fémárúgyár Rt. (Ersten Österreichischen Zünder- und Metallwarenfabrik AG.) néven folytatta a gyártást.

Az 1900-as évek elejére a gránáttestet áttervezték. Az ólomköpenyt leesztergálták és egy vörösréz vezetőgyűrüvel látták el. Egy 1906-ban kiadott szabályzatban ez a gránát már szerepelt az 1861 és 1861/95M ágyúk lőszerei között. 1914-ig biztosan alkalmazták ezeket a gránátokat. Ezt támasztja alá a Müszaki Katonai Bizottság (Technisches Militar Komittee - TMK) tervrajza ebből az évből, amelyen a gránát az „átalakított $15 \mathrm{~cm}$ M61 gránát” nevet viseli. Még ebben az évben a $15 \mathrm{~cm}$-es $1880 \mathrm{M}$ mozsárhoz és a 15 cm-es $1894 \mathrm{M}, 1899 \mathrm{M}, 1899 / 4 \mathrm{M}$ tarackokhoz is rendszeresítették ezt a gránátot. A mozsárhoz 7 különböző 1893M $1 \times 3 \mathrm{~mm}$-es lőportöltetet rendszeresítettek. A legkisebb $0,12 \mathrm{~kg}$, a legnagyobb $0,375 \mathrm{~kg}$ tömegü volt. A tarackokhoz 8 különböző tömegű 1893 M $1 \times 4$ és $2 \times 4$ mm-es lőportöltetet használtak. A legkisebb $0,25 \mathrm{~kg}$ volt $172,3 \mathrm{~m} / \mathrm{s}$ kezdősebességgel, a legnagyobb töltet $0,71 \mathrm{~kg}$, ami 314 $\mathrm{m} / \mathrm{s}$ kezdősebességet eredményezett. A lőpor begyújtásához már 1880/7M dörzsgyújtót alkalmaztak.

1916-ban az 1861/1M gránátok közül több is csőrobbanást okozott. A vizsgálatok alapján a tüzérség műszaki főfelügyelője a következőket állapította meg:

A gyújtószerkezetek idő előtti működését a biztosítólemez karmainak lövés előtti lehajlása okozta. A biztosítólemez elég erős ahhoz, hogy a szállítás közbeni rázkódásokat kibírja. Ezt szállítási próbákkal igazolták is. A gyújtószerkezet javára írták, hogy a világháború addig eltelt két évében csak kétszer fordult elő csőrobbanás az átalakított 15 cm-es 1861/1M gránátokkal. A császári és királyi 16 . hadtest parancsnoksága utasította a császári és királyi 58.

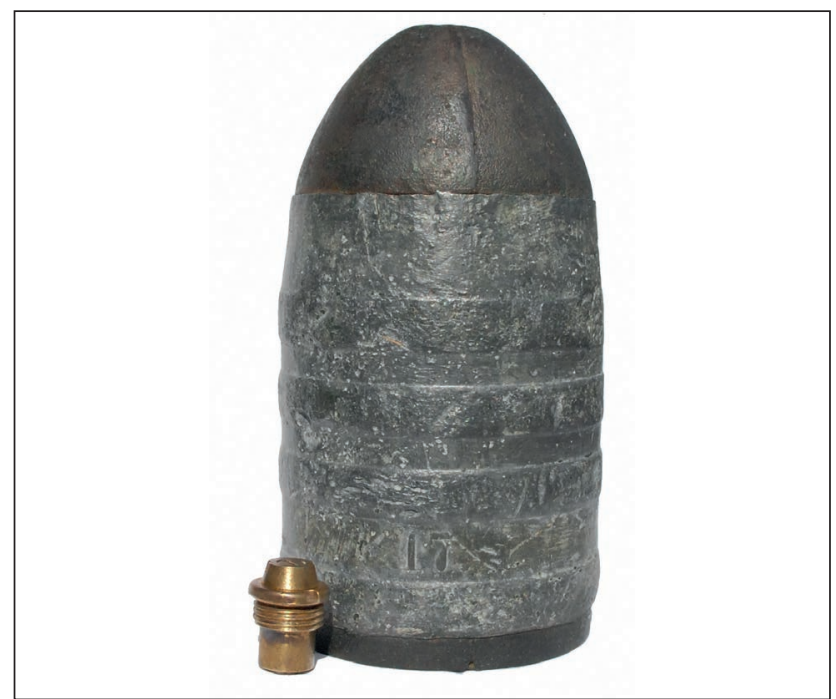

8. ábra. A 15 cm-es 1861/1M gránát és gyújtószerkezete

tartalék tábori tüzérdandár parancsnokságát arra, hogy az általuk kirendelt tűzszerész vizsgálja meg a dandár lőszerkészletét és az esetlegesen kifogásolható gránátokat Laibach-ba (Ljubljana) küldje. Ezzel egy időben a lőszergyárakat figyelmeztették arra, hogy az elkészült gyújtószerkezetek leejtését kerüljék.

1917-ben az átalakított 1861/1M gránátok használatát a 15 cm-es 1894M, 1899M, 1899/4M tarackoknál megtiltották. A gránátokat csak a $15 \mathrm{~cm}$-es $1880 \mathrm{M}$ mozsarak lőhették. Ez év tavaszán a Hadseregfőparancsnokság tájékoztatta a csapatokat, hogy ezeket a gránátokat hamarosan kivonják a rendszerből.

\section{9. ábra. Az 1880-7M, az 1893M és az 1859M dörzsgyújtók} replikái

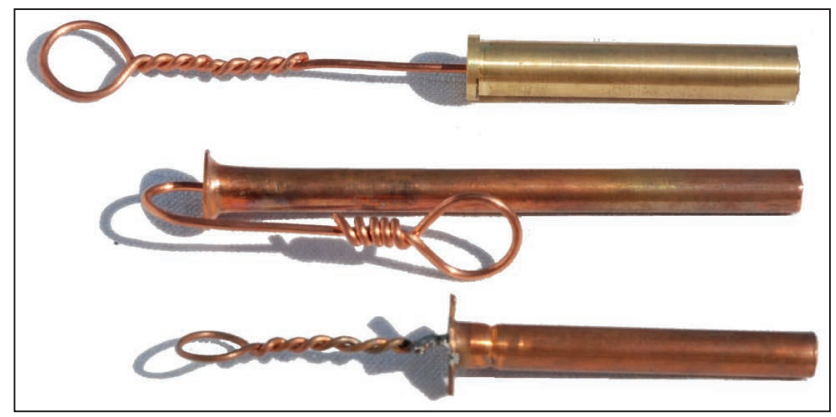

2. táblázat. Az alkalmazott lövegek föbb adatai

\begin{tabular}{|l|c|c|c|}
\hline & $\begin{array}{c}15 \mathrm{~cm}-\mathbf{1} \\
1861 / 80 \mathrm{M} \text { és 1861/95M } \\
\text { ágyúk }\end{array}$ & $\begin{array}{c}15 \mathrm{~cm} \text {-es 1880M mozsár } \\
\text { öntöttvas }\end{array}$ & $\begin{array}{c}15 \mathrm{~cm} \text {-es 1894M, 1899M } \\
\text { és 1899/4M tábori } \\
\text { tarackok }\end{array}$ \\
\hline A cső anyaga & $3086 \mathrm{~mm}$ & $1200 \mathrm{~mm}$ & $2000 \mathrm{~mm}$ \\
\hline A cső teljes hossza & $2685 \mathrm{~mm}$ & $577 \mathrm{~mm}$ & $1280 \mathrm{~mm}$ \\
\hline A huzagolt rész hossza & $30 \mathrm{db}$ & $36 \mathrm{db}$ & $36 \mathrm{db}$ \\
\hline Huzagok száma & $1,5 \mathrm{~mm}$ & $1,5 \mathrm{~mm}$ & $1,5 \mathrm{~mm}$ \\
\hline Huzag mélysége & $2860 \mathrm{~kg}$ & $625 \mathrm{~kg}$ & $1120 \mathrm{~kg}$ \\
\hline A cső tömege a zárral & $80 \mathrm{~kg}$ & $66 \mathrm{~kg}$ & $76 \mathrm{~kg}$ \\
\hline A zár tömege & $6400 \mathrm{~m}$ & $3500 \mathrm{~m}$ & $6000 \mathrm{~m}$ \\
\hline Maximális lőtávolság & &
\end{tabular}




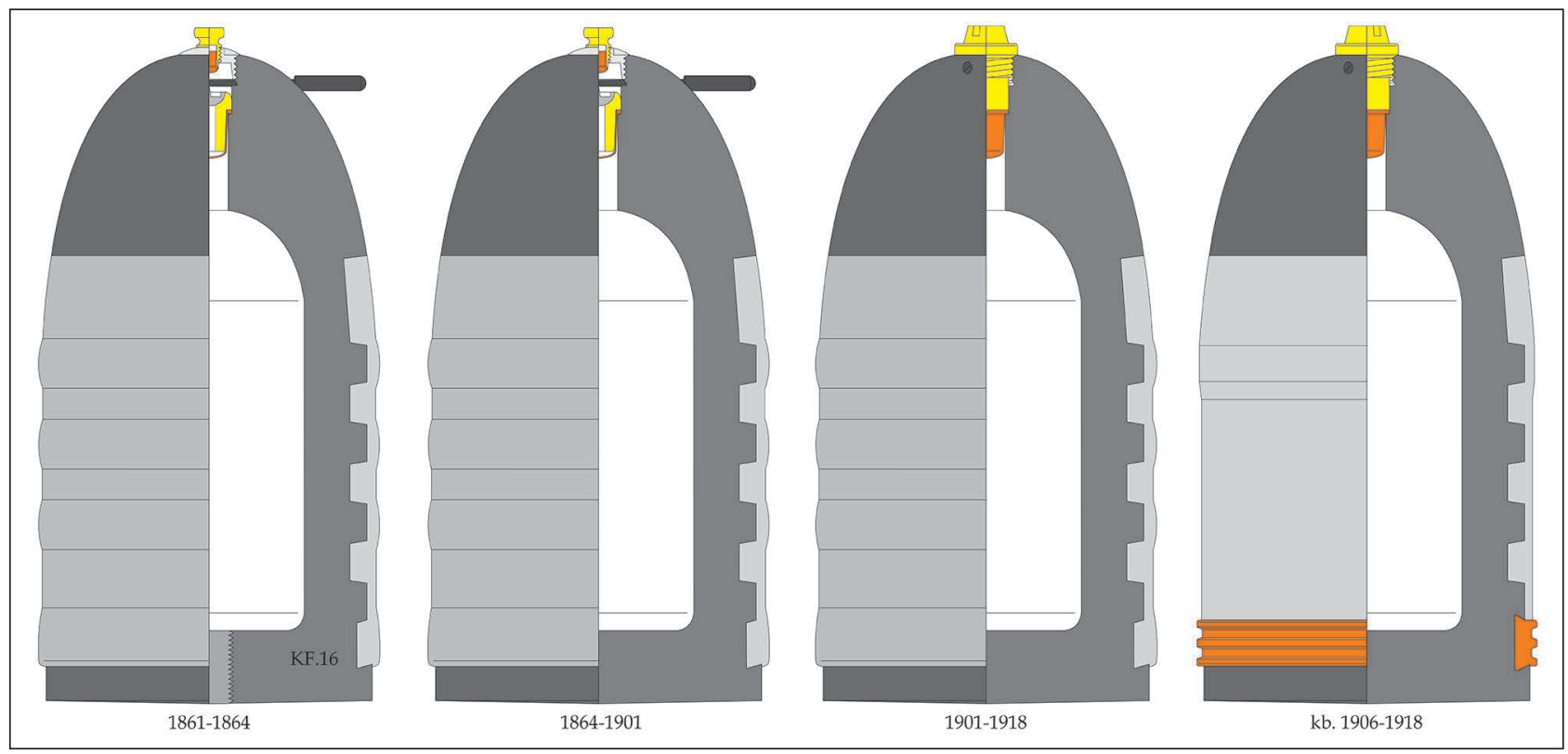

10. ábra. A különböző $15 \mathrm{~cm}$-es $1861 \mathrm{M}$ gránátok, és rendszerben tartásuk dátumai

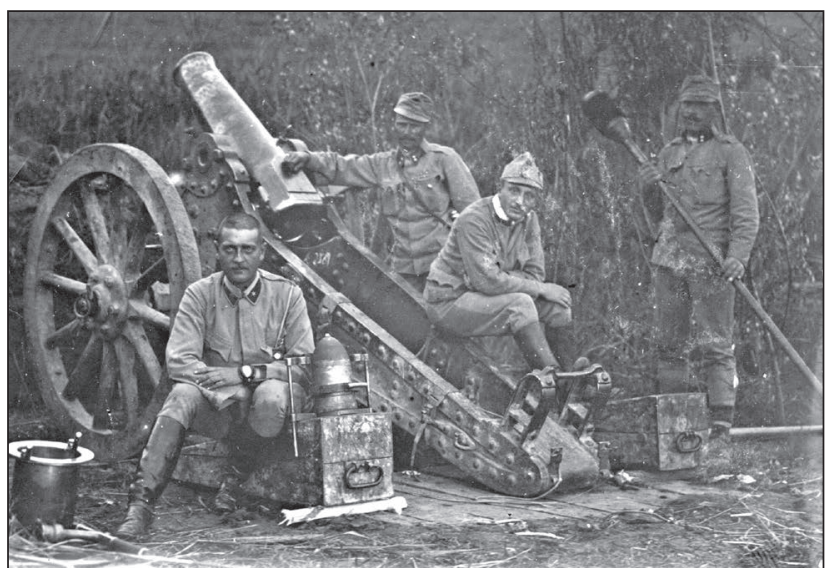

11. ábra. Egy $15 \mathrm{~cm}$-es 1899/4M tarack és kezelői egy $1861 / 1 M$ gránát mellett, valahol a fronton

Az 1861M és az ebből kialakított 1861/1M gránátok legnagyobb hibája a teljes tömeg 15\%-át kitevő ólomköpeny volt. Ez lövéskor sokszor leszakadt és a repeszképzésben sem volt jelentős szerepe, ugyanis a puha ólom túl nagy darabokra (kb. tenyérnyi) szakadt. A gránát robbanó hatása is csekély volt. A robbanóanyag kamrája relatíve kicsi volt. Az akkoriban használt feketelőpor az 1890-es évekre elavult robbanóanyagnak számított, gránátok töltésére már nem alkalmazták.

Véleményünk szerint az átalakított 1861/1M gránátok nem váltották be a hozzájuk füzött reményeket. Amennyivel kevesebb ólomra, annyival több vörösrézre volt szükség a gyártásukhoz. 1915-ben a monarchia színesfémhiányban szenvedett, ezért az átalakított gránátok gyártását abbahagyták. Az lőszertervezők azon gondolata, hogy egy már meglévő, nagy mennyiségben rendelkezésre álló gránátot megpróbáltak az új ágyúkhoz rendszerbe állítani, jó gondolatnak tűnik. A tervezésnél megtettek mindent, amit meglehetett. Egy ólomköpenyes gránátot ennél egyszerủbben nem lehetett átalakítani. A vezetőgyűrűs változat nem hozott áttörést, de az 1861/1M gránáttal együtt 1918-ig rendszerben maradt.

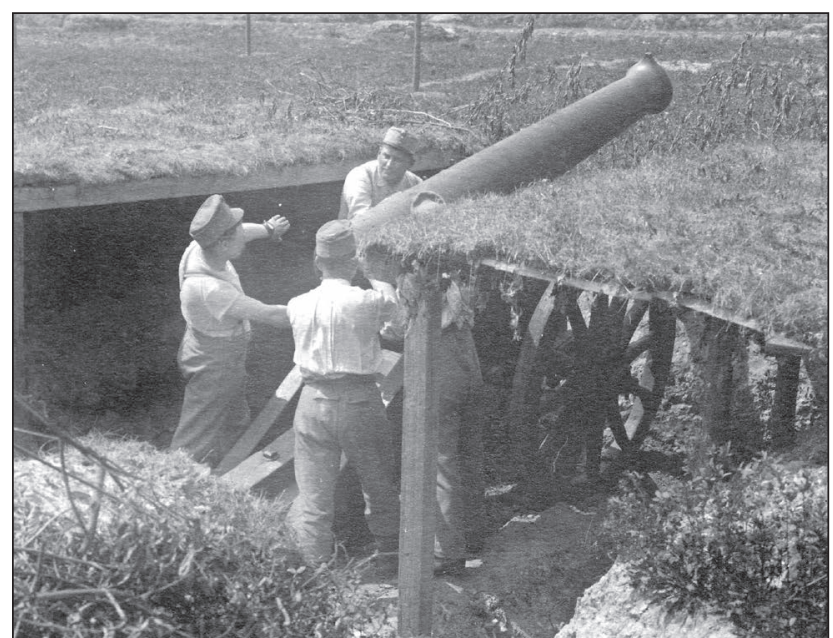

12. ábra. Egy $15 \mathrm{~cm}$-es $1861 \mathrm{M}$ Wahrendorff ágyú a lengyel fronton 1916-ban

\section{FELHASZNÁLT FORRÁSOK}

Artillerie-Unterricht für die Festungs- und Küsten-ArtillerieCompanien, Bécs, 1866;

Tabellen zur Kriegsfeuerwerkerei für die kaiserlichkönigliche Artillerie, 1868;

G. Csurusky: Tabellen über Artillerie-Munition, Bécsújhely, 1893;

Fegyvertan. Tankönyv a M. Kir. Honvéd Ludovika Akadémia számára, II. kötet. Budapest, 1899;

Artillerie-Unterricht für die k.u.k Kriegsmarine, I. Theil, Pola, 1903:

G-43 Artillerieunterricht für die k.u.k Festungsartillerie, I. Teil, 1. Heft, Bécs, 1906;

G-43 Artillerieunterricht für die k.u.k Festungsartillerie, I. Teil, 3. Heft, Bécs, 1907;

Artillerie-Munitions-Merkblatter, Bécs, 1918;

M. Christian Ortner: The Austro-Hungarian Artillery from 1867 to 1918. Bécs, 2007. 